\title{
SMALL-SCALE LIVESTOCK FARMERS' PARTICIPATION IN MARKETS: EVIDENCE FROM THE LAND REFORM BENEFICIARIES IN THE CENTRAL KAROO, WESTERN CAPE, SOUTH AFRICA
}

\author{
Cheteni, $\mathrm{P}^{1}$ and Mokhele, $\mathrm{X}^{2}$ \\ Correspondence Author: P. Cheteni. Email: pcheteni@icloud.com
}

\begin{abstract}
Since the launch of the Land Redistribution for Agricultural Development (LRAD) programme by the government, several small-scale farmers have slowly integrated into the mainstream markets. The main objective of the study was to evaluate and analyse the factors affecting participation in mainstream markets by the small-scale livestock farmers in the Central Karoo, Western Cape Province of South Africa. A sample of 36 small-scale farmer projects was purposively selected from the study area, and the data was collected using a semi-structured questionnaire. Thereafter a multinomial regression model was applied to the primary data. The results show that age, farming experience, number of beneficiaries, employment status and farmer training have a strong positive effect on the likelihood of small-scale livestock farmers marketing their sheep to the mainstream markets such as abattoirs and auctions. Furthermore, distance to the nearest market, access to market infrastructure and access to credit have a negative impact on the likelihood of those participating in the formal markets. The study suggests that the government should address the challenges faced by the small-scale farmers through interventions and improving access to markets.
\end{abstract}

Keywords: Factors, LRAD, small-scale, mainstream markets, Central Karoo, multinomial model

\section{INTRODUCTION}

The livestock sub-sector is an important agricultural stronghold that contributes immensely to improving the livelihoods of the rural poor in South Africa. The reason is that the livestock production, for example cattle/ sheep, plays a vital role through food provision by strengthening the household-economy through the provision of draught power, organic fertilizer, and fuel. Livestock plays multiple roles in the lives of the poor and meets the multiple objectives that are desired by the resource-poor farmers (Chimonyo et al., 2000). Furthermore, it is important to mention that South Africa produces $21.4 \%$ of the total meat produced on the continent of Africa and $1 \%$ of global meat production. Thus, the livestock sector contributes approximately $49 \%$ of agricultural output and provides $36 \%$ of the population's protein needs, hence, it is considered the largest national agricultural sector (Department of Agriculture, Forestry and Fisheries (DAFF), 2012).

The South African government introduced the Land Reform Intervention in 1994. The Land Redistribution for Agricultural Development Programme (LRAD) was intended, among other objectives, to ensure that poor rural communities gain access to land as a productive asset for

\footnotetext{
${ }^{1}$ Cheteni, P., PhD in Agricultural Economics, University of Fort Hare, PBX 1314 Alice, 5700, South Africa ${ }^{2}$ Mokhele, X., Agricultural Officer, Western Cape Department of Agriculture, Beaufort West, Cape Town, South Africa
} 
agricultural purposes. Another intervention by the South African government was the introduction of the Marketing of Agricultural Act of 1996 to cease the control boards. The Act was intended to promote free and open agricultural commodity markets and provide access to small-scale farmers and other formerly deprived farmers in output markets (Meyer-Stamer \& Waltring, 2007). The long-term objective was for small-scale farmers to create a stepping-stone towards becoming fully-fledged commercial farmers in the country.

Over the past years, studies have focused on sheep production and productivity, however, the literature on marketing challenges faced by sheep farmers in participating in the mainstream markets is still limited (Musemwa et al., 2007). Montshwe (2006) pointed out that small-scale livestock farmers face marketing challenges among other factors. For instance, South Africa off-take rates in the small-scale livestock sector are much lower than in the commercial sector, and this, according to Montshwe (2006), highlights the problems that are faced by the smallscale farmers. Since the implementation of the LRAD programme in the Western Cape, very little has changed in terms of food security levels and poverty amongst the beneficiaries of the Land Reform programme. Market off-take is still perceived to be low in communities that benefited from the project. Furthermore, land reform farmers still find it increasingly difficult to access the mainstream markets, gain access to credit, and realise good returns for their products as most of them still sell their livestock through informal markets (Musemwa et al., 2007). In most cases, they receive lower prices for their livestock through these marketing channels. While anecdotal evidence points to a disjoint between what the government aims to achieve on the LRAD programme and the current progress in the programme, numerous reports have highlighted challenges faced by small-scale livestock farmers. Given the desire showed by the South African government in addressing the plight of small-scale farmers, this paper aims to contribute to the land reform programme discourse by providing advice on how best the government may help the small-scale farmers. We do not engage with the merits and demerits of the programme, but exclusively focus on the determinants of small-scale farmers' participation in mainstream markets. To date, no study has focused on the LRAD programme beneficiaries, making this paper a pioneer of the land reform programme debate.

Small-scale farmers struggle to access markets due to a range of factors such as poor infrastructure, lack of information, insufficient expertise, and inability to conclude contractual agreements (Cheteni, 2017; Cheteni, Mushunje \&Taruvinga, 2014). These problems result in their exclusion from the mainstream markets (Makhura, 2001). Therefore, they are constantly trapped in market constraints since it is difficult to change these challenges on their own (Fenwick \& Lyne, 1999).

This study adds to the growing literature on small-scale farmer participation in mainstream markets by focusing exclusively on farmers residing in the Central Karoo in the Western Cape. As previously mentioned, the small-scale farmers do face insurmountable challenges in selling their livestock, especially at a profit. Therefore, it is critical that a study advises the South African government on how best to integrate such small-scale farmers into the main economy and possibly increase their contribution to the gross domestic product (GDP).

\subsection{Objective}

The objective of the study was therefore to investigate factors that affect small-scale farmers' participation and their access to livestock mainstream markets. 


\section{OVERVIEW OF THE PROGRAMME}

To address the challenges that were created by the apartheid legacy, the South African government launched the land reform programme. This was done through the Department of Land Affairs (DLA), and the main focus of the programme was to empower black farmers (DLA, 2001). As referred by the DLA (2000), the LRAD programme was meant to create emerging black farmers. The strategic aims of the programme included the following:

- Improving nutrition and income of the poor who want to farm on any scale;

- Decongesting overcrowded former homeland areas;

- Contributing to the redistribution of $30 \%$ of South African agricultural land over 15 years; and

- Expanding opportunities for women and young people who stay in rural areas.

To complement the aims of the programme, grants were established. In order to access grants, beneficiaries need to contribute to the establishment of the project (DLA, 2001). This contribution can be in any form, be it cash or kind, though, it needs to contribute to the project. However, each beneficiary has to at least contribute cash, labour and in-kind to be part of the project. For instance, those who contribute at least R5000 receive a minimum grant of R20 000. According to the DLA (2001), the larger the contribution, the larger grant. Furthermore, the approval of the grant is dependent upon the viability of the proposed project and this includes the costs and profitability of the project.

\subsection{Livestock farmers marketing and distribution channels}

Marketing ensures that small-scale farmers are integrated into mainstream markets (Coetzee, Montshwe \& Jooste, 2005). Marketing provides an opportunity for livestock farmers to earn an income and contribute to poverty reduction efforts. Livestock farmers make use of several distribution channels to sell their products. Figure 1 illustrates the distribution channels used by livestock farmers. However, transportation and transaction costs determine the length of the distribution channel. Farmers can sell their livestock through a broker who then sells to local traders and customers. This channel is probably expensive for smallholder farmers because of the brokerage fee charged by the broker. As a result, few farmers use this route. The most frequently used selling channel is from the farmers directly to customers. This channel is favoured because it reduces costs such as transportation and transactions.

Shiferaw, Obare and Muricho (2006) pointed out that small-scale farmers preferred farm gate sales due to the fact that payments were immediate, and no transportation costs or taxation is incurred. However, Monsthwe (2006) claimed that farm gate prices are very low and sometimes marketing costs increase. In certain instances, farmers use auctions, abattoirs and butcheries. The choice of the distribution channel is dependent on cost and benefits of using such a channel. According to the National Department of Agriculture (2003), small-scale livestock farmers favoured private sales directly to consumers. Musemwa et al., (2008) pointed out that private sales were the shortest and most popular way of selling their products. 


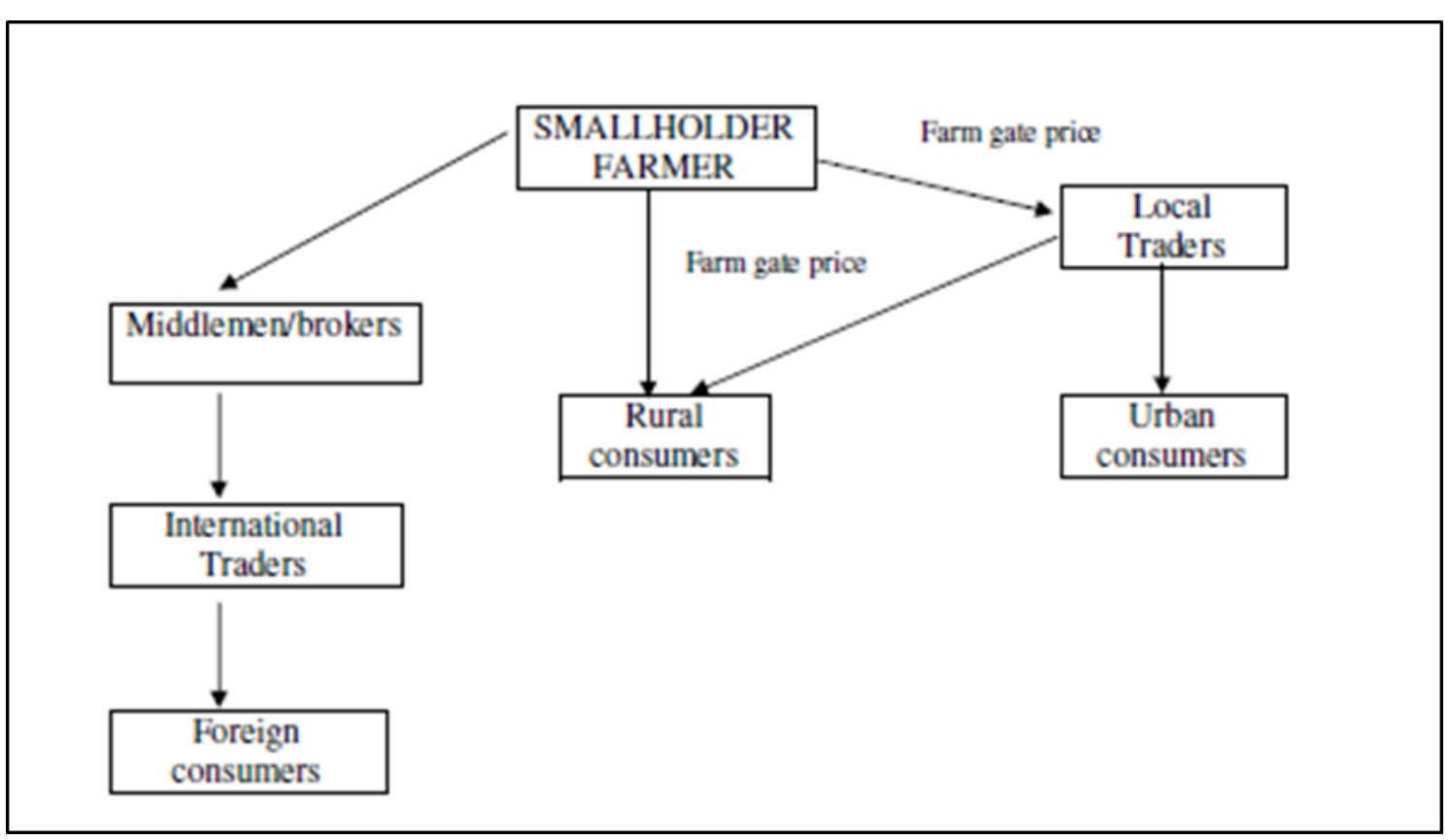

Figure 1: Livestock distribution channels

Source: Shiferaw et al. (2006)

\subsection{Conceptual framework}

The conceptual framework of the study assumes that factors such as institutional factors (group marketing, access to extension services, road infrastructure), socio-economic factors (age, education level, household income, vehicle ownership, gender), and market factors (market information, farming experience, distance to market) do affect market participation. The framework was developed based on the theoretical utility model discussed in the forthcoming sections. Figure 2 illustrates that for farmers to benefit from mainstream market participation, institutional, socio-economic and market factors need to be considered. Small-scale farmers can use the marketing channels with the hope of getting utility maximisation in the form of profits, which leads to economic development in the form of employment creation, food security and income. 
S. Afr. J. Agric. Ext.

Vol. 47 No. 1, 2019: 118 - 136

http://dx.doi.org/10.17159/2413-3221/2019/v47n1a494

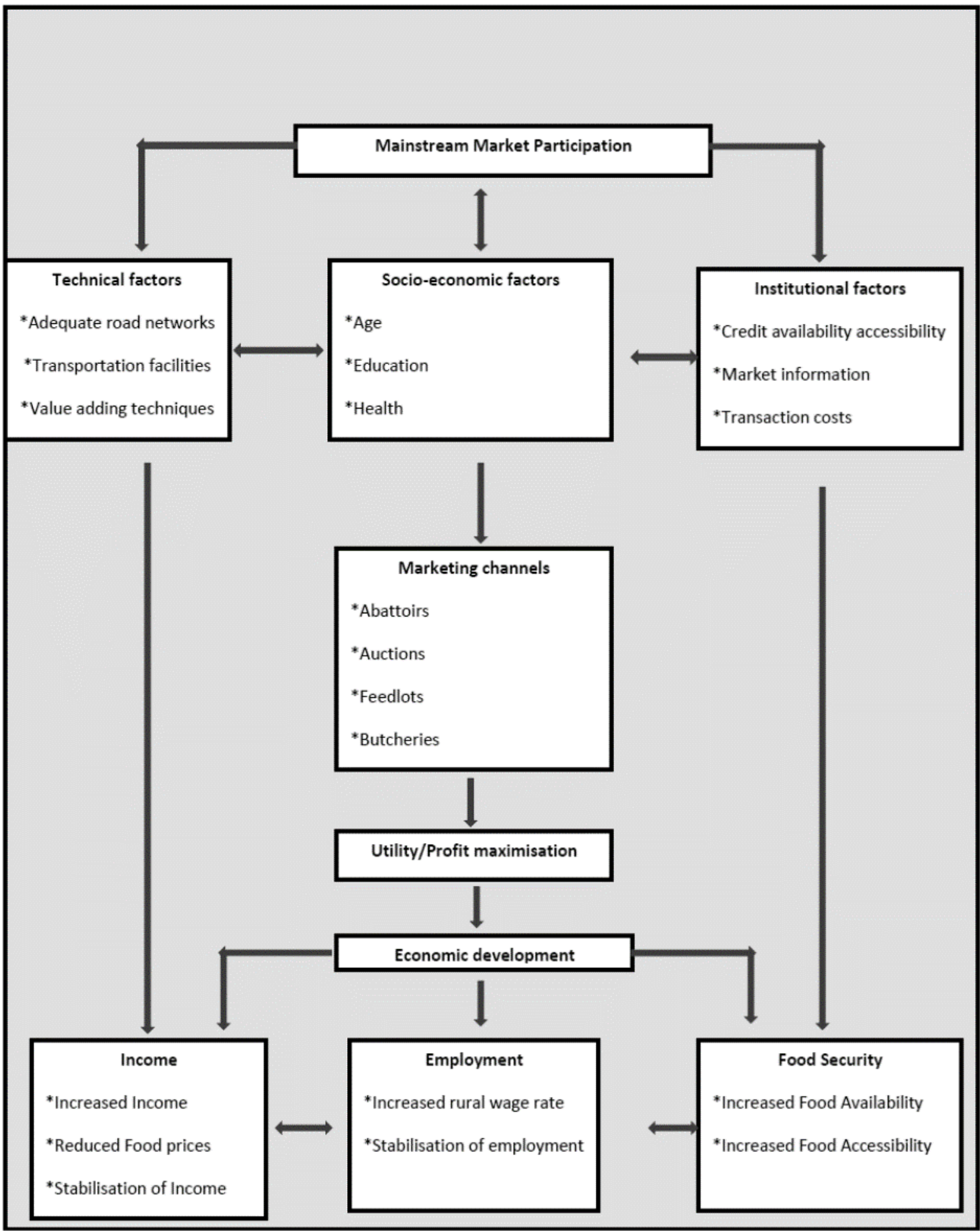

Figure 2: Conceptual framework

Source: Author Compilation (2017)
Cheteni and Mokhele

(License: CC BY 4.0) 


\section{STUDY AREA AND METHODS}

\subsection{Description of the study area}

The study was conducted in the Central Karoo (Beaufort West Municipality). Beaufort West is the largest town in the arid Great Karoo region and is known as the "Capital of the Karoo". It forms part of the Cape Karoo District Municipality. The town covers an area of $34.60 \mathrm{~km}^{2}$ with rain occurring in summer. Beaufort West is the economic, political, and administrative heart of the Central Karoo, located about $460 \mathrm{~km}$ North East of Cape Town. It is the centre of an agricultural district based mainly on sheep farming and is significant on the N1 national road (Integrated Development Plan, 2009). The location of the Central Karoo as a study area as well as the three districts constituting the Central Karoo are shown in figure 3.

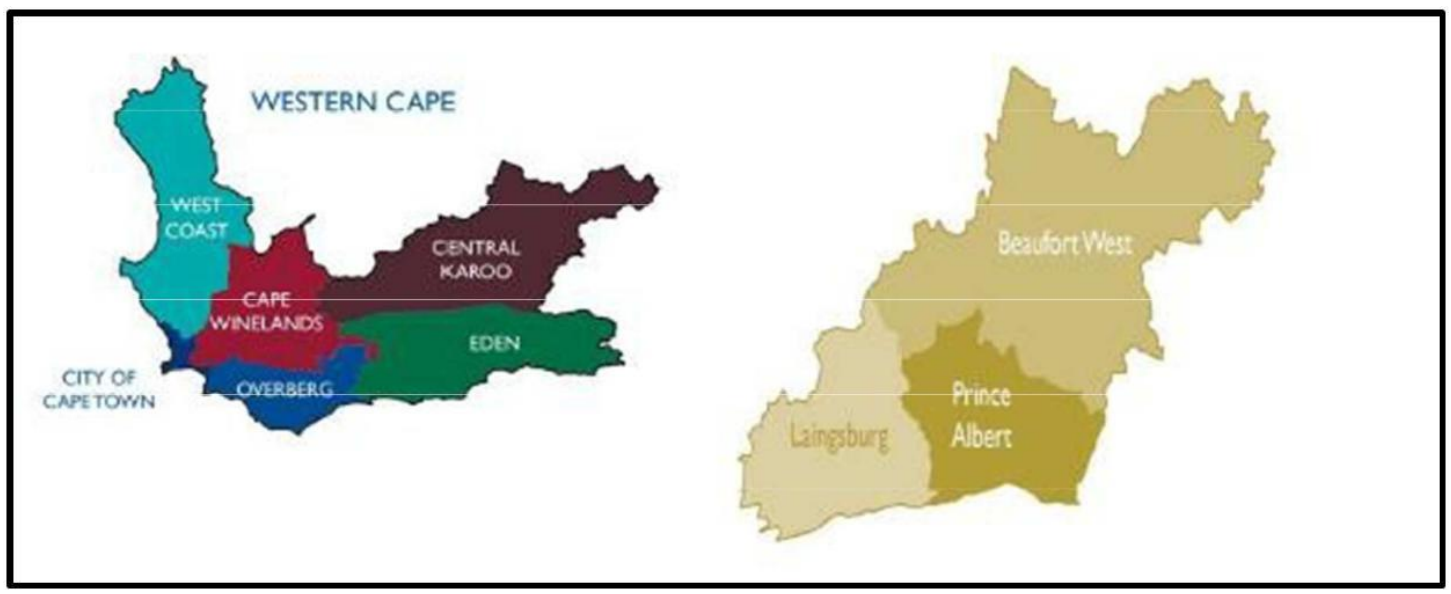

Figure 3: The Western Cape Province

Source: Central Karoo District Fact Sheet (2012)

Due to the dry climate, the potential for extensive agricultural practices is very limited. The region is famous for the production of sheep (Karoo lamb), leather, wool, mohair, and deciduous fruit, which caters mainly for the export market. Historically, the main driver of the local economy has been commercial farming, particularly of livestock. Agriculture forms the backbone of the Beaufort West economy and accounts for the largest labour force of the population.

\subsection{Units of analysis}

For this study, the units of analysis are the small-scale sheep farming projects that are beneficiaries of the LRAD programme in the Central Karoo area of the Western Cape Province. These projects are organised into legal business entities consisting of approximately 10 members or more. Each project comprises a board of executives (Chairperson, Secretary, Treasurer and additional members) that is responsible for driving interests of the members and the sustainability of the project. Furthermore, a manager is responsible for the daily farming operational functions of the farm.

\subsection{Data collection and statistical analysis}

The study area consisted of various agricultural projects (crop and livestock) and 36 sheep projects were identified purposively. The first step involved was identifying all the 36 LRAD 
sheep projects in the Central Karoo. Secondly, to identify the focus groups for group discussions, the projects were stratified into municipalities, and a random sampling method was used to identify two focus groups from each of the three municipalities. For this study, a multi-stage sampling method was used to identify the focus group questions. It was then modified to capture the relevant information. The questionnaire offered several open-ended and closed-ended questions. Open-ended questions are important as they allow respondents to freely express their views. Most of the questions were closed-ended to make the coding of the responses easy and to extract as much information as possible without taking too much of their time. Moreover, the questions were effectively formulated based on the objectives and research question of this study.

This study employed a cross-sectional research design and data were collected at one time. Data were collected through interviews with project managers and focus groups. The focus group discussions took place only when at least 6 representatives (members) of a project were present. According to Morgan and Krueger (1998), the appropriate size of a focus group ranges from six to 10 respondents. This range gives scope for a large range of different viewpoints and opinions while enabling all respondents to contribute without having to compete for time. Group interactions between members may encourage participants to make connections to various concepts through the discussions that may not occur during individual interviews. Therefore, 36 LRAD sheep projects and six focus groups were interviewed.

Descriptive statistics were applied to basic characteristics of the sampled projects. Tables illustrating the diverse factors affecting mainstream market participation were used. Market off-take rate for each trust (group) was calculated using the formula below:

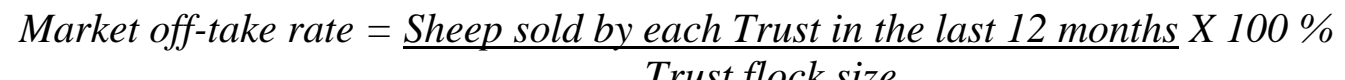
Trust flock size

\subsection{Utility maximisation theory}

In this framework, the economic agents' decisions are measured by the perceived utility or net benefit for an option. This model is based on a few assumptions. Firstly, households are assumed to be rational utility maximising units that select their preferences from a set of participation preferences in mainstream markets. Household decisions are based on farm households' utility obtained from participation subject to its reservation utility, farm household characteristics, and resource constraints. Therefore, the underlying farm household's utility from participating in mainstream market $q$ :

$U_{q} *=X \beta_{q}+K_{q} \alpha_{q}+\epsilon_{q}$

Where $\mathbf{X}$ is a vector of the observable independent variables; for instance, household characteristics (rent, landholding size, gender, education), $\mathbf{K}_{\mathbf{q}}$ is a vector of unobserved latent variables (farm potential that affects the choice to participate in the market and household earnings), $\boldsymbol{\epsilon}_{\mathbf{q}}$, is the error term which is assumed to be independent of $\mathbf{K}_{\mathbf{q}}$ yet $\boldsymbol{\beta}_{\mathbf{q}}$ and $\boldsymbol{\alpha}_{\mathbf{q}}$ are respective parameters associated with $\mathbf{X}$ and $\mathbf{K}_{\mathbf{q}}$. $\mathbf{U}_{\mathbf{q}} *$ is the unobserved farm household choice to participate in the mainstream market, $\boldsymbol{q}$ is the observed. If $\boldsymbol{K}$ is assumed to be latent denoting the specific market participation choice of farm household, then we can write $\boldsymbol{K}=\boldsymbol{q}$ where $\mathbf{U}_{\mathbf{q}} *=$ $\operatorname{Max}\left(\mathbf{U}_{\mathbf{z}}{ }^{*}\right)$. Where $\mathbf{U}_{\mathbf{z}}{ }^{*}$ is a complete set of optimising utility levels associated with $z$ 
participation decision that the farm household can make. Therefore, the expected household income to be achieved by each participating choice can be expressed as follows:

$E(y)=u^{*}\left(f \beta+I_{q} \lambda_{q}+i \gamma\right)$

Where $\boldsymbol{f}$ is a set of exogenous variables with associated parameters $\boldsymbol{\beta}$ and $\lambda_{\boldsymbol{q}}$, which represent the effects of participating in mainstream markets, related market in farm household earnings relative to non-participation. The expected earnings are also a function of the unobserved variables $\boldsymbol{K} \boldsymbol{q}$ with marginal effects parameters $\boldsymbol{\gamma}$.

\subsection{Data analysis}

The data collected from the field was cleaned, edited and coded to ensure consistency, uniformity and accuracy. It was coded on a Microsoft Excel Spreadsheet and exported to SPSS software. Two types of analysis were done, namely descriptive and econometric. In the descriptive analysis, percentages were used to explain the socio-economic status of respondents and other relevant factors. The multinomial model was used to analyse factors affecting smallscale sheep projects participating in mainstream sheep markets.

\subsection{Multinomial regression model}

The dependent variable has three types of market participation choices: (i) mainstream markets, (ii) informal markets, and (iii) both markets. The separation of these three groups demands a multinomial model because of these unique outcomes. A base outcome needs to be identified when running the model as a result. The base outcome is mainstream markets because the interest is in identifying factors that influence sheep mainstream market participation. Outcome 2 is the informal markets and outcome 3 is participation in both markets. The sign interprets the coefficient of the multinomial logit model, for example, a positive coefficient on independent variables means that the other outcome is more likely to be chosen than the base outcome. According to Gujarati (2003), it follows that a positive value indicates an increase in the likelihood that a household will change to the alternative option from the baseline group. However, a negative value shows that it is less likely that a household will consider the alternative (Pundo \& Fraser, 2006).

$$
Z i=\beta 0+\beta 1 X 1+\beta 2 X 2+\beta 3 X 3+\beta 4 X 4+\beta 5 X 5+\beta 6 X 6+\beta 7 X 7+\beta 8 X 8+\beta 9 X 9+\beta 10 X 10 \ldots \ldots \ldots+\mu
$$

Where $\beta 0$ is the intercept and $\beta 1, \beta 2, \beta 3 \ldots \ldots \ldots . . \beta i$ are the slope parameters which measure the change in $Z i$ for a unit in the change in explanatory variables. $X 1, X 2 \ldots . X 10$. These factors explain the participation decision or the probability that the ith farmer participates in livestock mainstream markets. These factors are explained as follows:

$\mathrm{Zi}=$ Decision to participate in mainstream sheep markets

$\mathrm{X} 1=$ Market information

$\mathrm{X} 2=$ Extension contact

$\mathrm{X} 3=$ Road infrastructure

$\mathrm{X} 4=$ Contractual agreement

$\mathrm{X} 5=$ Group marketing

$\mathrm{X} 6=$ Gender

$\mathrm{X} 7=$ Access to credit 
$\mathrm{X} 8=$ Membership in an association

$\mathrm{X} 9=$ Other business

$\mathrm{X} 10=$ Labour

$\mathrm{X} 11=$ Truck ownership

$\mu=$ error term

The variables that were used in the study are shown in Table 1.

Table 1: Variable description

\begin{tabular}{|c|c|c|c|}
\hline VARIABLE & TYPE & DESCRIPTION & SIGN \\
\hline \multirow[t]{3}{*}{ PART } & Categorical & \multirow{2}{*}{$\begin{array}{l}\text { Whether project participated in markets } 0=\text { formal } \\
\text { markets, } 1=\text { informal markets, } 2=\text { both markets }\end{array}$} & \\
\hline & & & \\
\hline & & Household characteristics & \\
\hline GEN & Dummy & Gender: $0=$ Female, $1=$ Male & $+/-$ \\
\hline PROJECT & Continuous & Number of members in a project & $+/-$ \\
\hline DIS & Continuous & Distance from the nearest mainstream market: $\mathrm{km}$ & $+/-$ \\
\hline EDU & Categorical & Education level & + \\
\hline ACC & Dummy & Access to credit: $1=$ yes, $0=$ Otherwise & + \\
\hline MKT & Dummy & Market information access: $1=$ Yes, $0=$ Otherwise & + \\
\hline EXT & Dummy & extension visits: $1=$ yes, $0=$ Otherwise & + \\
\hline APR & Continuous & Age of project: in years & + \\
\hline \multirow[t]{3}{*}{ MMS } & Dummy & \multirow{2}{*}{$\begin{array}{l}\text { Whether the project is a member of an } \\
\text { association: } 1=\text { yes, } 0=\text { Otherwise }\end{array}$} & + \\
\hline & & & \\
\hline & & Sources of Income & \\
\hline \multirow[t]{2}{*}{ PAE } & Dummy & \multirow{2}{*}{$\begin{array}{l}\text { Whether income was from paid employment: } \\
1=\text { Yes, } 0=\text { Otherwise }\end{array}$} & $+/-$ \\
\hline & & & \\
\hline \multirow[t]{2}{*}{ PENS } & Dummy & \multirow{2}{*}{$\begin{array}{l}\text { Whether income was sourced from other } \\
\text { business: } 1=\text { Yes, } 0=\text { Otherwise }\end{array}$} & $+/-$ \\
\hline & & & \\
\hline \multirow[t]{2}{*}{ REM } & Dummy & \multirow{2}{*}{$\begin{array}{l}\text { Whether income was sourced from remittances: } \\
1=y e s, 0=\text { Otherwise }\end{array}$} & $+/-$ \\
\hline & & & \\
\hline \multirow[t]{3}{*}{ OTHERB } & Dummy & \multirow{2}{*}{$\begin{array}{l}\text { Whether income is from other business: } 1=y e s, \\
0=\text { Otherwise }\end{array}$} & $+/-$ \\
\hline & & & \\
\hline & & Herd dynamics & \\
\hline VET & Dummy & Access to veterinary: $1=$ Yes, $0=$ Otherwise & $+/-$ \\
\hline LIVE & Continuous & Total number of sheep sold per year & + \\
\hline \multirow[t]{2}{*}{ HERDS } & Continuous & \multirow{2}{*}{$\begin{array}{l}\text { Total number of sheep owned excluding sold } \\
\text { during the year }\end{array}$} & $+/-$ \\
\hline & & & \\
\hline \multirow[t]{2}{*}{ LIVD } & Continuous & \multirow{2}{*}{$\begin{array}{l}\text { Number of sheep that die per year due to } \\
\text { accidents, natural factors }\end{array}$} & - \\
\hline & & & \\
\hline LAB & Dummy & Presence of hired labour: $1=y e s, 0=$ Otherwise & + \\
\hline VEH & Dummy & Vehicle ownership: $1=$ yes, $0=$ Otherwise & + \\
\hline \multirow[t]{2}{*}{ CONTRA } & Dummy & \multirow{2}{*}{$\begin{array}{l}\text { Contract agreements with buyers or sellers } 1= \\
\text { yes, } 0 \text { otherwise }\end{array}$} & + \\
\hline & & & \\
\hline MKTG & Dummy & Marketing in groups & $+/-$ \\
\hline
\end{tabular}




\section{RESULTS AND DISCUSSION}

\subsection{Demographic characteristics}

The results in Table 2 show that males had a large representation of $94 \%$ compared to the female representation of $6 \%$. All the projects are beneficiaries of the LRAD programme, therefore the results showed a bias to males. This was the case considering that animal rearing is usually done by males. In addition, the projects that were interviewed were sheep rearing projects only. Project members who are aged $40-64$ years comprised $29 \%$ of the sample and those who are older than 65 years constituted $71 \%$ of the sample. It was not surprising to see that older persons, as opposed to the youth, were leading projects. In addition, a total of $38 \%$ of the projects have project members from three to 10 people, and $44 \%$ of projects have members of between 11 and 20 . Only $18 \%$ of projects have members who are more than 20 but less than 65 . The conclusion is that the projects in the Central Karoo have an average membership of over 10 members, which is sizeable.

Table 2: Percentage distribution of respondents by demographic characteristics

\begin{tabular}{|c|c|c|c|c|c|}
\hline Gender: & $\%$ & Education level: & $\%$ & Gender: & $\%$ \\
\hline Males & 94 & None & 21 & Males & 94 \\
\hline \multirow[t]{3}{*}{ Female } & 6 & Primary & 47 & Female & 6 \\
\hline & & Secondary & 29 & & \\
\hline & & Tertiary & 3 & & \\
\hline $\begin{array}{l}\text { Age of project } \\
\text { members: }\end{array}$ & & Course attended: & & $\begin{array}{l}\text { Age of project } \\
\text { members: }\end{array}$ & \\
\hline $40-64$ & 29 & Farm management & 15 & $40-64$ & 29 \\
\hline \multirow[t]{4}{*}{65 and over } & 71 & Animal production & 35 & 65 and over & 71 \\
\hline & & Marketing & 35 & & \\
\hline & & Record keeping & 24 & & \\
\hline & & Budgeting & 6 & & \\
\hline $\begin{array}{l}\text { Project members in } \\
\text { numbers: }\end{array}$ & & Distance to market: & & $\begin{array}{l}\text { Project members in } \\
\text { numbers: }\end{array}$ & \\
\hline $3-10$ & 38 & $5-30 \mathrm{~km}$ & 24 & $3-10$ & 38 \\
\hline $11-20$ & 44 & $61-90 \mathrm{~km}$ & 35 & $11-20$ & 44 \\
\hline $21-65$ & 18 & $31-60 \mathrm{~km}$ & 41 & $21-65$ & 18 \\
\hline Employment status: & & Credit access: & & $\begin{array}{l}\text { Employment } \\
\text { status: }\end{array}$ & \\
\hline Employed & 21 & Land bank & 3 & Employed & 21 \\
\hline \multirow[t]{2}{*}{ Unemployed } & 79 & BKB & 24 & Unemployed & 79 \\
\hline & & No credit & 74 & & \\
\hline Extension: & & Farmer experience: & & & \\
\hline Monthly & 94 & $5-10$ yrs & 67 & & \\
\hline \multirow[t]{3}{*}{ Seldom } & 6 & $11-15 \mathrm{yrs}$ & 15 & & \\
\hline & & $16-20 \mathrm{yrs}$ & 13 & & \\
\hline & & 20 yrs plus & 5 & & \\
\hline
\end{tabular}

The employment status of members of the projects was classified into two classes, namely employed and unemployed. An analysis of the employment status of the participating projects 
in mainstream sheep markets suggests that the unemployed dominated the respondents in the study area. Table 2 shows that $79 \%$ of the project members were unemployed, which suggests a high dependency on subsistence activities or government grants for survival. Stats SA (2010) showed that most economic sectors including agriculture have shed a number of jobs between 2008 and 2010 because of the recession.

A total of $47 \%$ of the respondents had at least primary level education, $29 \%$ with secondary level, and only $2.9 \%$ with tertiary education. It was discovered that $21 \%$ had no education at all. Education influences the ability of projects to adapt to new marketing information and technology. Table 2 shows that $35 \%$ of project members had attended a marketing course, $24 \%$ attended record keeping and $21 \%$ on animal production. The results show that on average, every project member attended a course that was related to farming. Coetzee and colleagues (2005) stated that training received by small-scale farmers improved their knowledge and understanding of livestock production and marketing.

Distance has a major influence on transaction costs. Ouma, Obare and Staal (2003) found that the impact of distance, which requires transport of cattle to markets, results in imperfect and inefficient integrated markets and reduces producers' profit margin as it results in high transaction costs. Table 2 shows that $41 \%$ of projects were travelling 31-60 kilometres in order to market their sheep, 35\% travel 61-90 kilometres, and 24\% travel 5-30 kilometres. It was evident that the distance travelled by other projects especially from 61 to 90 kilometres had an effect on their mainstream market participation as they mostly market their sheep during seasonal periods such as Easter and just before Christmas. Most of the interviewed projects (74\%) had no access to credit, and $24 \%$ received credit from banks for production inputs, with only 3\% receiving credit from the Land Bank for capital. Cheteni (2017) observed that a lack of credit access is a major constraint for smallholder farmers in the developing countries. Therefore, due to the lack of capital investment, most of the projects will always struggle to attract investments or have collateral security.

Table 2 shows the number of years of farm experience of the sampled farmers. Farmer experience may influence the potential to participate in agricultural markets. It can be seen in Table 2 that at least every sampled farmer had 5 years' experience in farming and with some having over 25 years of farming experience. This, therefore, confirmed that an ageing population dominated the sample. Extension services are considered one of the most crucial information sources among farmers. In the Central Karoo, it has been noted that more LRAD projects make use of government extension services than private extension services. Every project that was interviewed used extension services.

\subsection{Herd dynamics}

The herd size dynamics helps to gauge the potential of the small-scale farmers in marketing their livestock. Thus, an increase in the herd size means the probability of participation in markets increases as well. Table 3 shows the number of live births, deaths, and the number of sheep sold. It can be seen from the table that more projects had over $25 \%$ of live births that added 101 to $286+$ sheep in their herds. This means the birth rate was high. Yet, projects that recorded deaths in more than 11 to 45 sheep per year accounted for $47 \%$ of the sample. Just over half of the projects (53\%) sold over 51 sheep per year. From the table, it can be seen that a number of projects own a sizeable number of sheep. 
Table 3: Herd Dynamics

\begin{tabular}{|l|l|l|l|l|l|}
\hline \multicolumn{2}{|l|}{ Live Birth Sheep } & \multicolumn{2}{l|}{ Sheep Deaths } & \multicolumn{2}{l|}{ Number of Sheep Sold per Year } \\
\hline & Percent & & Percent & & Percent \\
\hline $35-100$ & 44,1 & 2 to 5 & 32,3 & $15-30$ & 20,5 \\
\hline $101-285$ & 29,4 & 6 to 10 & 20,5 & $31-50$ & 26,4 \\
\hline $286+$ & 26,5 & 11 to 45 & 47,1 & $51+$ & 52,9 \\
\hline
\end{tabular}

\subsection{Market off-take rate of the projects}

Market off-take rate is generally the proportion of animals leaving the total heard due to deaths, slaughters, sales and other transactions as a percentage of the adjusted number of animals in a given year (Ba et al., 1996). In this study, the off-take was calculated based on the number of sheep sold over the flock since the main objective of the study was to try to assess the participation of LRAD projects in the mainstream markets. The average market off-take rate for the projects was then used to achieve the results. The formula for the average off-take rate was as follows:

$$
\begin{aligned}
& \text { Average market off-take rate }=\frac{\text { Total sheep sold by projects in the last } 12 \text { months }}{\text { Total flock size of the projects }} 100 \% \\
& =\frac{810}{4210 \%} \\
& =19,2 \%
\end{aligned}
$$

The off-take rate was $19 \%$ in the Central Karoo. This was lower than the commercial rate of $25 \%$. Nkhori (2004) reported the off-take rate that was 5 to $10 \%$ in marginalised environments. Coetzee et al. (2005) acknowledge that low off-take rates are affected by time as well as markets where farmers sell. Similarly, Nyhondo et al. (2014) noted that progress has been made in the livestock market, although it has failed to stimulate the off-take rate. Musemwa et al. (2010) also recorded similar findings concerning a low off-take rate from smallholder farmers. Their study concluded that low off-takes were caused by the market unavailability, transport shortages, limited information access, and poor condition of cattle. This study agrees with other studies (Montshwe, 2006; Musemwa et al., 2008) that focused on livestock off-take rates in South Africa.

\subsection{Marketing channels used by projects}

The objective of this study was to identify the marketing channels used by the projects in selling their sheep. The most used channels were to sell the sheep directly from the farm to the abattoir. This was preferred because farmers would gain immediate access to money/cash and could sell a larger number of animals. According to project leaders, abattoirs also offered them better prices compared to auctions and farm gate prices. A further investigation into this practice revealed that abattoirs always have a ready market, therefore, farmers would rather sell to them. Thus, $65 \%$ of the sampled projects used that channel. Sometimes the projects sell their sheep at the farm gate to reduce transaction costs that are incurred in bringing sheep to a formal market. This meant that projects sell directly to consumers. This route, although fetching lower prices, were not usually preferred by projects unless in cases where they needed to generate 
revenue quickly. Several projects claimed that this marketing channel is prone to insecurities because customers seek to bargain for the lowest prices, yet the farmers seek high prices. A total of $32 \%$ of the projects were making use of this form of marketing channel. Lastly, some projects were taking the long route of selling their sheep. The sheep were sold to an auction then taken to abattoirs and then to the customer. This marketing channel was said to be the most uncommon one because it is costly and at the same time fetches lower prices. Several projects complained that using an auction to sell sheep was not a good idea because it is difficult to bargain with the buyer, and in certain instances, the brokers take advantage of their illiteracy and try to convince them to accept cheap prices. As a result, the majority of projects hardly use this marketing channel.

\subsection{Multinomial regression model results}

As illustrated in table 4, several variables influence market participation choices. Out of the 14 variables used in the model, a total of seven variables in informal and both marketing channels influence projects' participation in markets respectively.

\subsubsection{Age distribution of project managers}

The variable was found to be statistically significant at 0.034 with a negative coefficient of (.1.611) in the informal market choice and 0.018 in both market choices. The value of the odds ratio (36.07) indicates the higher probability of the variable influence on the mainstream market choice. The explanation for the negative coefficient could be that young project managers are expected to be the ones likely to participate in mainstream markets because of their risk-loving behaviour. Siziba et al. (2011) recorded a negative coefficient with regards to project participation in mainstream markets. In this case, it might mean that older project managers may be unwilling to participate in sheep markets based on their risk-adverse behaviour. It should be noted that age influence in mainstream market participation has been greatly debated in literature, and scholars and researchers agree that the influence can be positive and negative, based on other factors. For instance, Mushunje, Belete and Fraser (2003) pointed out that young farmers may fail to participate in markets due to lack of resources compared to older farmers who may find it easier to participate.

\subsubsection{Age of project}

This variable measured the number of years that projects have in farming. The variable was statistically significant at the $10 \%$ level and had a positive coefficient (2.694) for the informal market and 4.220 for both markets. However, the odds ratio was higher (70.83) for both markets compared to the informal marketing channel, which was at 4.763. This implies that as the number of years increases in practising agriculture, so does the likelihood of being involved with market participation in both marketing channels. One reason may be that projects that have been in operation for many years have developed some understanding on how the market operates and, therefore, improve decisions about participating (Makhura, 2001). Similarly, older projects with young members may have developed means of lowering costs to transport sheep to the marketplace. As a result, they may find it easier to participate in mainstream markets than younger projects with older members. 


\subsubsection{Flock size}

Total flock size has a direct influence on the participation of projects in the mainstream sheep markets. Large flock sizes generate a higher marketable surplus than small flocks (Fidzani, 1993). The variable was found to be strongly statistically significant at 1 percent level with an odd ratio value of 1.48 in the informal market and 3.15 in both market choices. From the sampled respondents, projects that had large sheep numbers were more willing to participate in mainstream markets in order to generate more income for their farming operations, compared to those with few sheep numbers. The study was in accordance with the findings of Fidzani (1993).

\subsubsection{Credit access}

The variable credit access is statistically significant for mainstream and informal (0.021) and both market choices (0.039). This positive relationship explains that an increase in credit access improves the likelihood of projects shifting from informal or both markets to the mainstream markets. The higher odds ratio for informal and both markets challenges suggest that there is a higher probability of shifting from informal to both marketing channels with an increase in credit access. Thus, it can be concluded that credit access is important regardless of the marketing channel chosen.

Access to credit for productive investments usually comes from poor projects that are less riskaverse and enables them to overcome bankruptcy constraints, making it possible to undertake investment that can boost production and increase participation in mainstream markets. The results obtained in this study show that the access to credit variable significantly influences the likelihood of participating in mainstream markets. As highlighted in the descriptive results, access to credit was a large challenge, which is why its positive influence was expected. Lerman (2004) noted that agricultural credit plays a vital role in the process of smallholder commercialisation. Therefore, for the agricultural projects to compete equally with an established business in the market, access to credit needs to be addressed and improved.

\subsubsection{Market distance}

Distance has a major impact on transaction costs. The result indicates that there is an inverse relationship between distance and mainstream market participation. The variable was statistically significant at the $1 \%$ level with a negative coefficient of 2.30 for both market channels. This means that as distance to markets declines, the likelihood of participating in mainstream markets increases by $23 \%$. Similarly, a negative relationship (-2.47) was found between the informal channel market and distance to market. This was expected to be true in that from the sampled projects, those that are located close to the market places had little challenges in accessing mainstream markets as compared to those that were far away. However, increased participation takes place when buyers come close to projects because of ease of market accessibility. Furthermore, the closeness of buyers means that the projects can reduce transaction costs incurred in travelling to urban sheep markets. Other researchers also found similar results as this study concerning distance. The impact of distance (which requires transport of sheep to markets) results in imperfect and inefficient integrated markets and reduces producers' profit margin as it results in high transaction costs (Ouma et al., 2003). 
Vol. 47 No. 1, 2019: 118 - 136

http://dx.doi.org/10.17159/2413-3221/2019/v47n1a494

Table 4: Multinomial logistic results

\begin{tabular}{|c|c|c|c|c|c|c|c|c|c|c|}
\hline \multirow{2}{*}{\multicolumn{3}{|c|}{ VARIABLE }} & \multicolumn{4}{|c|}{ OUTCOME 2 - INFORMAL MARKET CHANNEL } & \multicolumn{4}{|c|}{ OUTCOME 3 - BOTH CHANNELS } \\
\hline & & & Coeffici & Std. Error & Significan & Odds ratio & Coefficient & Std. Error & Significanc & Odds \\
\hline \multicolumn{3}{|c|}{ Age of project (AGP) } & 2.694 & 1.072 & $0.014 * *$ & 4.763 & 4.220 & 1.835 & $0.004 * * *$ & 70.83 \\
\hline \multicolumn{3}{|c|}{ Age of managers (AGM) } & -1.611 & 0.950 & $0.037 * *$ & 0.167 & 3.840 & 0.840 & $0.018 * *$ & 36.07 \\
\hline \multicolumn{3}{|c|}{ Education level (EDU) } & 0.634 & 0.686 & 0.845 & 1.383 & 1.170 & 2.492 & 0.172 & 3.229 \\
\hline \multicolumn{3}{|c|}{ Flock size (FLOS) } & 0.221 & 0.950 & $0.058 *$ & 1.482 & 1.450 & 2.683 & $0.021 * *$ & 3.150 \\
\hline \multicolumn{3}{|c|}{ Employment status (EMPL) } & -0.250 & 0.574 & 0.724 & 0.870 & -1.155 & 1.584 & 0.540 & 0.310 \\
\hline \multicolumn{3}{|c|}{ Project training (PATRA) } & 0.874 & 0.841 & 0.350 & 2.683 & 2.989 & 2.711 & 0.188 & 20.92 \\
\hline \multicolumn{3}{|c|}{ Veterinary services (VET) } & 0.754 & 0.678 & 0.361 & 2.919 & 1.320 & 1.493 & 0.390 & 2.758 \\
\hline \multicolumn{3}{|c|}{ Type of road (ROADTY) } & 1.564 & 1.086 & 0.201 & 3.685 & 0.365 & 0.259 & 0.840 & 1.490 \\
\hline \multicolumn{3}{|c|}{ Access to infrastructure } & 2.650 & 1.020 & $0.018 * *$ & 12.789 & -0.656 & 0.056 & 0.770 & 0.583 \\
\hline \multicolumn{3}{|c|}{ Marketing information (MKT) } & 0.590 & 0.761 & 0.543 & 1.973 & 0.259 & 1.683 & 0.980 & 1.106 \\
\hline \multicolumn{3}{|c|}{ Contract agreements } & 0.854 & 0.745 & 0.263 & 2.456 & 2.877 & 1.382 & $0.041 * *$ & 13.01 \\
\hline \multicolumn{3}{|c|}{ Vehicle ownership } & 0.463 & 0.642 & 0.248 & 2.433 & 0.356 & 1.444 & 0.889 & 1.660 \\
\hline \multicolumn{3}{|c|}{ Credit access (ACC) } & 1.890 & 0.846 & $0.021 * *$ & 5.760 & 1.960 & 1.320 & $0.039 * *$ & 9.467 \\
\hline \multicolumn{3}{|c|}{ Market distance (DIS) } & -2.466 & 1.434 & $0.035 * *$ & 11.095 & -2.300 & 2.196 & $0.003 * * *$ & 0.117 \\
\hline \multicolumn{3}{|c|}{ INTERCEPT } & -4.874 & 2.680 & 0.043 & - & -16.07 & 4.400 & 0.040 & - \\
\hline \multicolumn{4}{|c|}{ Goodness-of-Fit } & & & & & & & \\
\hline & Chi- & Df & Sig. & & & & & & & \\
\hline Pearson & 111.742 & 172 & 0.160 & & & & & & & \\
\hline Deviance & 86.201 & 172 & 0.998 & & & & & & & \\
\hline
\end{tabular}

$* * * \mathrm{p}<0.01, * * \mathrm{p}<0.05,{ }^{*} \mathrm{p}<0.1$ significant level 


\subsubsection{Access to infrastructure}

It was not surprising that access to infrastructure could have a positive influence on market participation. The variable was statistically significant at the 5\% level with a positive coefficient of 2.65 for the informal marketing channel. This meant that as one increases infrastructure by a unit, holding other factors constant, projects have an increased likelihood to participate in markets for sheep. This is further supported by a high odds ratio (12.78). Takavarasha and Jayne (2004) pointed out the usefulness of good market infrastructure as one of the contributors towards market participation. It was evident from the results that several projects are being affected by the non-availability of good infrastructure, thereby contributing towards their lack of participation in formal markets.

\subsubsection{Contract agreements}

According to Table 4, a positive and significant (0.041) relationship was found between informal market participation and the availability of contractual agreements. This implies that projects usually increase their market participation with the availability of contractual agreements. This is likely due to the security obtained when signing contracts. Most of the contractual agreements have a stipulated price and guaranteed payment. Contract farming improves agricultural production for contract projects benefiting from increased incomes, enables better access to services and resources and creates new opportunities to participate in markets. The value of the odds ratio (13.01) supports the higher probability of the variable's influence on the mainstream market choice. In terms of the goodness-of-fit test for a logistic regression model, the results in Table 4 indicate that the model fits well. Thus, both the Pearson and Deviance chi-square show that the multinomial model fits well and is well suited to predict the influence of the independent variables.

\section{CONCLUSION AND RECOMMENDATIONS}

The study revealed that small-scale farmers in the LRAD sheep projects struggle to access mainstream markets. Only three channels were used by projects in accessing markets with the most dominant one involving the use of abattoirs and auctioneers. However, the study noted that although the shortest route of a producer to a consumer does not incur many costs, most projects would prefer to avoid it based on low prices that are created. It was also established that although the government rolled the LRAD programme to target emerging farmers, it was difficult to identify the benefits in its current state, although some employment opportunities have been created up to date.

Moreover, increasing the involvement of youth in agriculture is a crucial element that should be worked on by both government and the private sector. Access to relevant information for farmers remains a serious obstacle inhibiting them from fully participating in mainstream markets. Making information available would help in farmers' participation in markets. One of the key routes in developing the sheep projects that benefited from the LRAD programme is through the commercialising of the small-scale sector. The market off-take rate was quite lower than the commercial sector. This highlights that projects need to be encouraged to participate in activities that improve their grazing land, sheep flocks, and obtaining market-related information. 
The present study identified factors that were affecting the participation of projects in the mainstream sheep markets. Therefore, a study that will identify factors influencing commercial farmers to participate in markets may provide valuable insight on how emerging projects can participate in mainstream markets.

\section{REFERENCES}

BA, S.B., UDO, H.M.J. \& ZWART, D. (1996). Impact of veterinary treatments on goat mortality and off take in the semi-arid area of Mali. Small Ruminant Research, 19(1): $1-8$.

CHETENI, P., 2017. Sustainability development: Biofuels in agriculture. Environmental Economics, 8(2):83-91.

CHETENI, P., MUSHUNJE, A. \& TARUVINGA., A., 2014. Barriers and incentives to potential adoption of biofuels crops by smallholder farmers in the Eastern Cape Province, South Africa. Environmental Economics, 5(3):71-78.

CHIMONYO, M., KUSINA, N.T., HAMUDIKUWANDA, H., NYONI, O. \& NCUBE, I., 2000. Effects of dietary supplementation and work stress on ovarian activity in nonlactating Mashona cows in a smallholder farming area of Zimbabwe. J. Animal Sci., 70(2):317-323.

COETZEE, L., MONTSHWE, B.D. \& JOOSTE, A., 2005. The marketing of livestock on communal lands in the Eastern Cape Province: Constraints, challenges and implications for the extension services. S. Afr. J. Agric. Ext., 34(1):81-103.

DEPARTMENT OF AGRICULTURE, FORESTRY AND FISHERIES, 2012. Economic review of the South African agriculture [viewed 13 March 2017]. Available from: http://www.nda.agric.za/docs/statsinfo/EcoRev2011-12.pdf.

DEPARTMENT OF LAND AFFAIRS, 2001. Land redistribution for agricultural Development (LRAD). Government Printer: Pretoria.

FENWICK, L.J. \& LYNE, M.C., 1999. The relative importance of liquidity and other constraints inhibiting the growth of small-scale farming in KwaZulu-Natal. Development Southern Africa, 16(1):141-155.

FIDZANI, H., 1993. Understanding cattle off-take rates in Botswana. PhD Thesis, Boston University.

FOOD AND AGRICULTURAL ORGANIZATION, 2012. Facilitating access of rural youth to agricultural activities [viewed 10 February 2017]. Available from: https://www.ifad.org/documents/38714170/39135645/Facilitating+access+of+rural+y outh+to+agricultural+activities.pdf/325bda30-ac08-494f-a37d-3201780a5dff

GUJARATI, D.N., 2003. Basic Econometrics. New York: McGraw Hill Book Co.

INTEGRATED DEVELOPMENT PLAN, 2009. Beaufort West Municipality Draft Integrated Development Plan. Western Cape: Government Printer. 
INTEGRATED SUSTAINABLE RURAL DEVELOPMENT STRATEGY, 2004. Integrated rural strategy [viewed 14 March 2017]. Available from: http://www.info.gov.za/otherdocs/2000/isrds.pdf.

LERMAN, Z., 2004. Successful land individualization in Trans-Caucasia: Armenia, Azerbaijan, Georgia. Lanhan, MD: Lexington Books.

MAKHURA, M.T., 2001. Overcoming transactions costs barriers to market participation of smallholder farmers in the Northern Province of South Africa. PhD thesis, University of Pretoria.

MEYER-STAMER, J. \& WALTRING, F., 2007. Linking value chain analysis and the 'making markets work better for the poor' concept. Duisburg, Dortmund: GTZ.

MONTSHWE, B.D., 2006. Factors affecting participation in mainstream cattle markets by small-scale cattle farmers in South Africa. M.Sc Thesis, University of the Free State.

MORGAN, D.L. \& KRUEGER, R.A., 1998. The Focus Group Kit. Thousand Oaks, CA: SAGE Publications, Inc.

MUSEMWA, L., CHAGWIZA, C., SIKUKA, W., FRAZER, G., CHIMONYO, M. \& MZILENI N., 2007. Analysis of cattle marketing channels used by small-scale farmers in the Eastern Cape Province, South Africa. Livestock Res. Rural Dev., 19(9):131.

MUSEMWA, L., MUSHUNJE, A., CHIMONYO, M., \& MAPIYE, C., 2010. Low cattle market off-take rates in communal production systems of South Africa: Causes and migration strategies. Journal of Sustainable Development in Africa. 12(5):209-226

MUSEMWA, L., MUSHUNJE, A., CHIMONYO, M., FRASER, G., MAPIYE, C. \& MUCHENJE, V., 2008. Nguni cattle marketing constraints and opportunities in the communal areas of South Africa. Afr. J. Agric. Res., 3(4):239-245.

MUSHUNJE, A., BELETE, A. \& FRASER, G., 2003. Technical efficiency of resettlement farmers of Zimbabwe. Contributed Paper Presented at the 41st Annual Conference of the Agricultural Economic Association of South Africa (AEASA), Pretoria, South Africa (Vol. 13).

NATIONAL DEPARTMENT OF AGRICULTURE, 2003. Red Meat Marketing [viewed 21 May 2017]. Available from: http://www.nda.agric.za/docs/MarketExtension/7Livestock.pdf

NKHORI, P.A., 2004. The impact of transaction costs on the choice of cattle markets in Mahalapye District, Botswana. M.Sc Thesis, University of Pretoria.

NYHONDO, B., MMBENGWA, V., BALARANE, A. \& NGETU, X., 2014. Formulating the least cost feeding strategy of a custom feeding programme: A linear approach.

OUMA, E., OBARE, G. \& STAAL, S., 2003. Cattle as assets: Assessment of non - market benefits of cattle in smallholder crop - livestock systems. Contributed paper at the $25^{\text {th }}$ 
International Conference of Agricultural Economists (IAAE), Durban, South Africa. (pp. 16-22).

PUNDO, M.O. \& FRASER, G.C.G., 2006. Multinomial logit analysis of household cooking fuel choice in rural Kenya: The case of Kisumu district. Agrekon, 45(1):24-37.

SHIFERAW, B., OBARE, G. \& MURICHO, G., 2006. Rural institutions and producer organizations in imperfect markets: Experiences from producer marketing groups in semi-arid eastern Kenya. Socioeconomics and Policy Working Paper no 23.

SIZIBA S., NYIKAHADOZI, K., DIAGNE, A., FATUNBI, A.O. \& ADEKUNLE, A.A., 2011. Determinants of cereal market participation by sub-Saharan Africa smallholder farmer. Journal of Agriculture and Environmental Studies, 2(1).

STATS SA, 2010. Employment in Agriculture. Government Printer: Pretoria

TAKAVARASHA, T. \& JAYNE, T.S., 2004. Toward improved maize marketing and trade policies to promote household food security in Southern Africa [viewed 18 July 2017]. Available

from: http://www.aec.msu.edu/maizemarket/JayneTakavarashaSummary.pdf. 